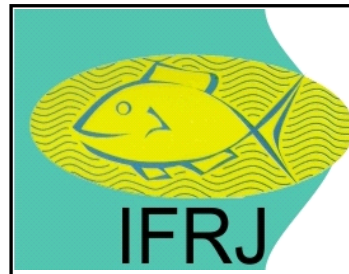

Available online at: http://ejournal-balitbang.kkp.go.id/index.php/ifrj

e-mail:ifrj.puslitbangkan@gmail.com

INDONESIAN FISHERIES RESEARCH JOURNAL

Volume 25 Nomor 2 December 2019

p-ISSN: 0853-8980

e-ISSN: $2502-6569$

Accreditation Number RISTEKDIKTI: 21/E/KPT/2018

\title{
SOUTHERN BLUEFIN TUNA (Thunnus maccoyii) CAUGHT BY INDONESIA'S TUNA LONGLINERS IN THE SPAWNING AREA
}

\author{
Fathur Rochman ${ }^{\star 1}$, Ni Luh Watiniasih ${ }^{2}$ and Luh Putu Eswaryanti K. Yuni ${ }^{3}$ \\ ${ }^{1}$ Research Institute for Tuna Fisheries, Ministry of Marine Affairs and Fisheries, Bali-Indonesia \\ ${ }^{2}$ Fisheries and Marine Department, Udayana University, Bali-Indonesia \\ ${ }^{3}$ Mathematics and Natural Sciences, Udayana University, Bali-Indonesia \\ Received; May 02-2019 Received in revised from September 16-2019; Accepted September 20-2019
}

\begin{abstract}
Southern Bluefin Tuna in spawning area of the Eastern Indian Ocean where the Indonesian's longliners operated has a specific character in term of size, age, sex-specific growth rate and the population. The aims of this study are to determined changes in size/age, sex-specific growth rate and virtual population analysis of Southern Bluefin Tuna (SBT) in the spawning area. This study is important to find out the successful management of SBT in spawning area by looking at the catch at age/size movement, sex-specific growth analysis and the estimation of the population by virtual population analysis. In this study, we were used 452 pairs of otolith with fish sized from 134-196 cmFL and fish aged from 8-20 years. The growth equation was $L_{t}=191\left(1-e^{-0,167(t+1,081)}\right)$. Catch at age structure was distributed from 5-22 years with mean and mode of age were 9.63 and 9 years. The distribution of mode changed from year to year shifting to a younger fish. In 2012, the mode was 10 years but entering 2013-2014 the mode was shifted to 6 years. In 2015-2017, the mode was increased from 7 years (2015) to 8 years (2016) and 9 years (2017). The fishing pressure happened in the age group under 20 years. In 2012 to 2014, the highest fishing pressure respectively obtained in the age group of 13 to 11 years with an average length of 167 to $174 \mathrm{cmFL}$. Entering 2015 and 2016, the highest fishing pressure obtained in the age group of 6 years with an average length of $138 \mathrm{cmFL}$. The exploitation rate ranged from 0.14 /year to 0.25 /year meaning that the exploitation was in optimal condition.
\end{abstract}

Keywords: Southern Bluefin Tuna; spawning area; otolith, catch at age structure, virtual population analysis

\section{INTRODUCTION}

Growth rate, catch at age structure and virtual population analysis (VPA) can provide an overview and information about fishing pressure, population and exploitation status of the fish stock in certain water. High fishing pressure can be seen from a reduction of the relative abundance of larger fish or older fish (Sparre \& Venema, 1998). In some cases, fish stock assessments only seen from spawning stock biomass (SSB) reproductive potential and ignoring the change that may occur in size and age structure of the spawning stock population (Farley et al., 2014; Setyadji, 2015). Therefore it is necessary to recognize and carry out a comprehensive monitoring of size and age change in spawning population as well as the impact of fishing pressure on the species in stock assessment process The population and exploitation status of the species can also be determined by interpreting statistical data using the VPA method
(Sparre \& Venema, 1998). Age determination using a hard part of the body such as otolith is important for long-lived species where not all fish size can be a good predictor of age (Farley et al., 2014). Changes in the catch at age structure and VPA of spawning stock biomass can be used as the main indicator of the stock status of this species (Farley et al., 2014; Rochman, 2019).

Southern Bluefin Tuna (SBT) Thunnus maccoyii, is a long-lived, late-maturing and reaching maximum size of at least $200 \mathrm{cmFL}$ and maximum age 40 years old (Gunn et al., 2008). Spawning ground area of SBT is known in the eastern of the Indian Ocean between Indonesia and west coast of Australia where the Indonesian fisheries in particular longline fishery operated. Mature fish begin to migrate to this area from the southern Indian Ocean (Tasman Sea, Australia) in September until April each year (Farley \& Davis, 1998; Patterson et al., 2008; Evans et al., 
2012). Indonesia began a member of the Commission for the Conservation of Southern Bluefin Tuna (CCSBT) in 2008, and in periods of 2018-2020 Indonesia has 1,023 tonnes of the Total Allowable Catch (TAC) as CCSBT member (CCSBT, 2018). Indonesian Tuna Fishery has began to catch this species in spawning ground area since 1976 (CCSBT, 2018). The production increased rapidly from only a few tonnes in year 1976 to 2,504 tonnes in 1999 and then declined to only 565 tonnes in 2003 and 633 tonnes in 2004 (CCSBT, 2018). The decreasing number of SBT caught by the Indonesian longliners caused by the increasing number of the exploitation which was signed by the decreasing number of nominal CPUE globally in the period of 1970 to 2007 (CCSBT, 2017). Generally, Southern Bluefin Tuna is the main target of Indonesian longliner along with Yellowfin Tuna and Bigeye Tuna. However, during the SBT season (September-April) in each year, this species become the first target compared to the Yellowfin Tuna and Bigeye Tuna. Indonesian longline fisheries are high capital fisheries with the highest capital expenditure is in fuel cost reaching up to $50-60 \%$ of the total cost (Rochman et al., 2016). Indonesian tuna longliner tries to reduce this cost with stayed at sea for much longer periods ( \pm 9 month) and used carrier vessel to bring back fish to the fishing port and to support a logistic to the fishing vessel (Rochman et al., 2016).

Actually, spawning stock biomass of SBT in the Indian Ocean remain at a low level to be $13 \%$ of the initial stock in 2017 but there has been an improvement of spawning stock biomass since the previous stock assessment at level $5 \%$ of original biomass 2011 and 9\% of the original biomass 2014 (CCSBT, 2018). Therefore, it was important to estimate the size and age distribution of SBT caught by Indonesian longliner for monitoring on the changes of size and age structure in spawning population.

Even though SBT caught by Indonesia's tuna longliner cannot represent all of the whole tuna in spawning ground area but historically, Indonesian SBT was larger than those Japan SBT caught in spawning ground area (Farley et al., 2014). The majority of SBT caught by Indonesia's tuna longliners were in shallow water inside the Indonesian Exclusive Economic Zone (IEEZ) and teritorial water nearshore off Java island 10-15 ${ }^{\circ} \mathrm{S}$ and $100-120^{\circ} \mathrm{E}$ (Rochman, 2019) and Japan longliner operated in deep water outside the IEEZ (Farley et al., 2014). A larger size of SBT was found in shallow water of tropical water where Indonesian longliner able to catch (Farley et al., 2014; Rochman, 2019). Therefore, it's recommended that Southern Bluefin Tuna caught by Indonesia's longliner can be used as a reference point in spawning stock assessment of SBT in the Indian Ocean.

Data used in this study were based from a longterm monitoring program (enumeration) in the past six years and combined with otolith data used for age estimation. The aims of this research are to determined changes in size/age, sex-specific growth rate and virtual population analysis of SBT in the spawning ground area.

\section{MATERIALS AND METHODS Data Source and Collection}

In this study, we used two types of primary data that is otolith data and catch monitoring data of SBT caught in spawning ground area of the Eastern Indian Ocean. The otoliths data used in this study were sagittal otolith data obtained from 462 SBT landed in Benoa port Bali during the fishing season in the period of January to December 2017. The reading of the otolith aging was occurred in Research Institute for Tuna (RITF) laboratory in April 2018. We used the Average Percentage Error (APE) to validate the precision of intra and inter-reader difference. The estimation of APF level can be known by the formula $\operatorname{APE}_{\mathrm{j}}=100 * \frac{1}{R} \sum_{\mathrm{i}=1}^{R}\left[\frac{X_{1 j}-X_{j}}{x_{j}}\right]$ given by Beamish \& Fournier, (1981) Where $X_{i j}$ is the ith age estimate of the jth fish, $X_{i}$ is the mean of readings for the th fish and $R$ is the number of times each fish is aged. The APE level recommend a maximum level of $10 \%$.

The otolith data includes fish morphometry data consisting of fork length ( $\mathrm{cmFL}$ ) and gilled gutted fish weight $(\mathrm{kg})$. The proportion of the samples and fish morphometry consider being a balance between length class. All of the sagittal otoliths were removed, prepared and read following the techniques described by Clear et al. (2000) and also described by Shimose \& Ishihara, (2015).

The enumeration data of Benoa port was chosen because Benoa port was the biggest fishing port in Indonesia where $85 \%$ of SBT landed (Satria et al., 2012; Farley et al., 2014). The enumeration data of SBT landed in Benoa port consist of the name and the number of the vessel, fish morphometry (length and weight), grade of fish quality (export, reject and local) and the coverage of data sample. The grade of fish depended on flesh quality which was influenced by fish handling, the condition of the fish at the first capture and length of trip (fresh and frozen fish). The catch of SBT obtained from spawning ground area located near the port base in the south of Java, Bali and Nusa Tenggara intended for the export market 
(Figure 1). The frozen SBT was obtained from a nursery ground area which was far from the main fishing port and intended for the local market. The location of nursery ground area is in Western Australia in the coordinate of $\left(20^{\circ}-35^{\circ} S\right.$ and $\left.75^{\circ}-110^{\circ} \mathrm{E}\right)$ (Proctor et al., 2006; Lin \& Tzeng, 2010; CCSBT, 2016). This study was focused on the data of fresh SBT because it was in accordance with the initial objectives of the study i.e. to determine the growth, catch at age structure and virtual population analysis of SBT as spawning stock biomass (SSB).



Figure 1. Fishing ground area of Indonesia Southern Bluefin Tuna (Thunnus maccoyii) in the Eastern Indian Ocean. (Rochman, 2019).

\section{Growth and Catch at Age Structure Analysis}

To determine the age structure of Indonesian SBT, age-length key (ALK) and Von Bertalanffy Growth Function (VBGF) were developed using the age samples of the otolith. ALK and VBGF are expected to interpret the catch monitoring data in the periods of 2012-2017. The ALK obtained based on the relationship between the growth rate $\left(\frac{\Delta L}{\Delta t}\right)$ and the average of fork length $\bar{L}(t)$ using the equation $=(t)$, given by Gulland \& Holt, (1959) where $a$ is the coefficient of direction, $b$ is the intersection constanta on the $\mathrm{Y}$ axis, is length difference $(\mathrm{cm})$ and is age difference (year).

Growth curve of SBT well described using the Von Bertalanffy Growth Model (VBGF) (Gunn et al., 2008; Lin \& Tseng, 2010; Farley et al., 2014). The standard of VBGF used in this study was using the equation $L_{t}=L_{n}\left(1-e^{-K(t-t)}\right)$ (Sparre \& Venema, 1998) where $L t$ is length at the age of $t(\mathrm{~cm}), L$,is the asymptotic length $(\mathrm{cm}), K$ is the growth coefficient, $t$ is the time needed to reach a certain length (year) and $t_{0}$ is theoretical age when the length is zero (year). The growth coefficient $(K)$ recognized from the regression coefficient value of ALK, where $K=b$ and $L_{\text {, }}$ (Gulland \& Holt, 1959). The theoretical age when the length is zero $\left(t_{0}\right)$ is determined by Pauly (1984) with the empirical equation $\log _{10}\left(-t_{0}\right)=0.3922-0.2752\left(\log _{10}\right.$ L.) $-1.038\left(\log _{10} K\right)$.

There was a total of 52,477 samples of fresh SBT in this study but only 13,701 specimens were fitted for length $(\mathrm{L})$-weight $(\mathrm{W})$ relationship (LWR). This was because not all fish samples can be measured in length and weight together due to the fast handling and transport in sampling location. The relationship between length-weight of 13,701 samples can be used to estimate the length and weight of the other data samples. The parameter $(a, b)$ of the power equation describing the length-weight relationship $W(g g t)=a$ $F L(g g t)^{b}$ given by Klawe (1980) where $W(g g t)$ is the total weight in gilled and gutted process (kg), FL (ggt) is fork length $(\mathrm{cm})$ and $a, b$ are parameters of the LWR.

\section{Virtual Population Analysis (VPA)}

Virtual Population analysis (VPA) is an analysis of fisheries commercial catch data obtained from fisheries statistic. This method is obtained by combining and analyzing the distribution of the cohort with the age reading of the catch. VPA is conducted to obtain the information on a fish population that should have been in water to produce the current catch. According to Fry (1949) virtual population is a population that is analyzed from the methods based on real catch data with the assumptions of natural 
mortality (M) and final fishery mortality. This method is used by the calculation of the total recruitment in the first cohort. The estimation of natural mortality $(\mathrm{M})$ is based on the historical life of the fish itself. By knowing the natural mortality value, the countdown can be done to get to know how many fish in this cohort that lives year after year and ultimately can be known how much recruitment is there. In the end, it can be known as the coefficient value of fishing mortality $(F)$ of the data.

The natural mortality (M) of SBT is estimated by the calculation of the natural mortality from the maximum age of the fish (otolith reading), for example, the maximum age of SBT is 25 years, the estimation of the natural mortality is $(1: 25)$ or 0.04 per year. Furthermore, the countdown is carried out from catch data monitoring (2012-2017) with the following formula: $N_{(t)}=\left[N_{(t+1)}{ }^{*} \exp ^{(M / 2)}+C_{(t)}\right]^{*} \exp ^{(M / 2)}$ given by Pope (1972) where $N_{(t)}$ is the number of fish in year $(\mathrm{t}), t$ is age of fish, $M$ is the natural mortality and $C_{(t)}$ is the number of catch in year $(\mathrm{t})$. The estimation of fishing mortality (F) can be known by the formula $F_{(t)}=I n-M$ given by Pope (1972). The total mortality $(Z)$ was determined by adding the natural mortality $(\mathrm{M})$ and fishing mortality $(F)$.

\section{RESULTS AND DISCUSSION Results}

\section{Growth}

There were 462 pairs of sagittal otolith in this study but only 452 pairs of sagittal otolith can be read of 189 pairs of male fish, 220 pairs of female fish and 43 others were unidentified. The result of otolith age reading are presented in Appendix 1 and the tabulation of length, weight, and age based on sex are shown in Table 1.

Table 1. The number of otolith samples, range (max, min and mean) of length, weight, and age of fish based on the reading of otolith increment of Southern Bluefin Tuna (Thunnus maccoyii) on January to December 2017.

\begin{tabular}{clrrr}
\hline Sex & & Length $(\mathrm{cmFL})$ & Weight $(\mathrm{kg})$ & Age (year) \\
\hline Male $(\mathrm{n}=189)$ & Minimum & 138.0 & 46.0 & 8.0 \\
& Maximum & 196.0 & 140.0 & 18.0 \\
& Mean & 164.0 & 86.6 & 12.7 \\
Female $(\mathrm{n}=220)$ & Minimum & 134.0 & 45.0 & 9.0 \\
& Maximum & 195.0 & 157.0 & 18.0 \\
& Mean & 159.4 & 79.2 & 13.0 \\
Unidentified (n=43) & Minimum & 140.0 & 45.0 & 10.0 \\
& Maximum & 184.0 & 160.0 & 20.0 \\
& Mean & 158.7 & 80.8 & 12.4 \\
\hline
\end{tabular}

The relationship between the growth rate () and the average of fork length $(\mathrm{t})(\mathrm{ALK})$ in each sex were $Y=-0.2297 F L+44.046\left(R^{2}=0.9471\right)$ for males, $Y=-$ $0.1268 F L+24.88\left(R^{2}=0.9426\right)$ for females and $Y=-$ $0.167 F L+31.815\left(R^{2}=0.9355\right)$ for combined sexes. Furthermore, The ALK was used to fit in Von Berthalanffy Growth Function (VBGF) to recognize a real growth pattern in SBT stock assessment. Growth coefficient $(\mathrm{K})$ were 0.2297 for males, 0.1268 for females and 0.167 for combined sexes. The asymptotic length $(\mathrm{L}$,) were $192 \mathrm{cmFL}$ for males, 196 $\mathrm{cmFL}$ for females and $191 \mathrm{cmFL}$ for combined sexes. After all of this parameters were known, $t_{0}$ can be recognized by Pauly (1984) equation where $t_{0}$ were 0.439 for males, -0.809 for females and -1.081 for combined sexes. The three of those growth parameter were then substituted into Von Berthalanffy Growth Function as follow: $L_{t}=192\left(1-e^{-0,2297(t+0,439)}\right)$ for males, $L_{t}=196\left(1-e^{-0,1268(t+0,809)}\right)$ for female and $L_{t}=191\left(1-e^{-}\right.$ $0,167(t+1,081)$ ) for combined sexes (Figure 2).

\section{Catch at Age Structure}

Catch at age structure of fresh SBT was distributed from the age of 5 years to the age of 22 years with an average of age was 9.63 years and a mode at age of 9 years. Catch at age structure also showed the normal distribution pattern where mode value was under the age of the first maturity (Figure 3). The distribution of catch at age structure showed that the 
mode changed from year to year leading to a younger fish. In 2012, the mode was 10 years but entering 2013-2014 the mode was shifted to 6 years. In 2015-
2017, the mode was increased from 7 years (2015) to 8 years (2016) and 9 years (2017) (Figure 4).

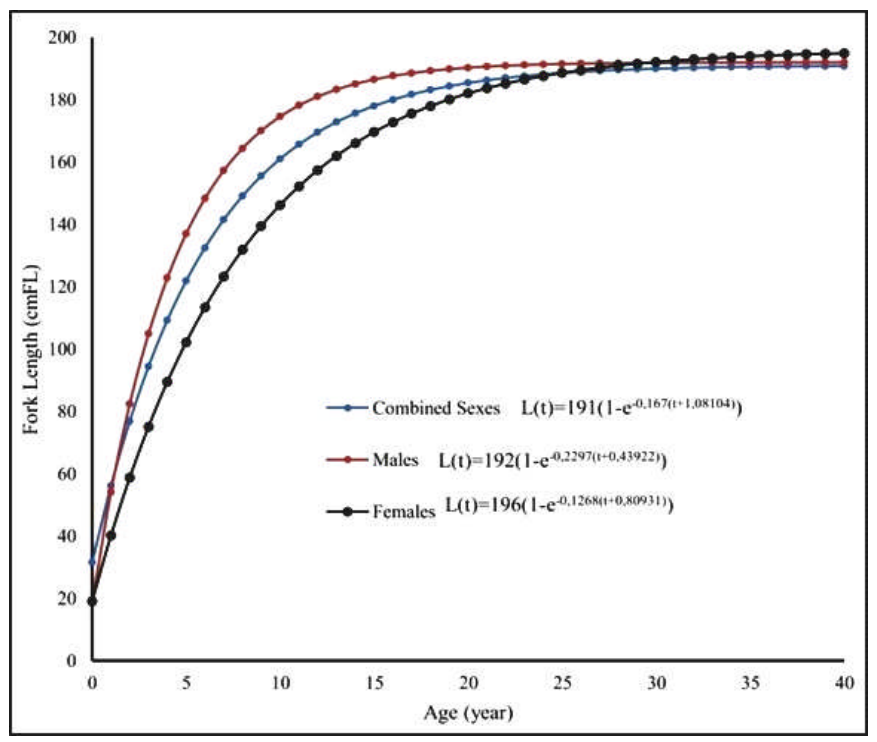

Figure 2. Von Bertalanffy growth curve of Southern Bluefin Tuna (Thunnus maccoyii) caught by Indonesian tuna longliner based on the otolith age estimation in the periods of January-December 2017.

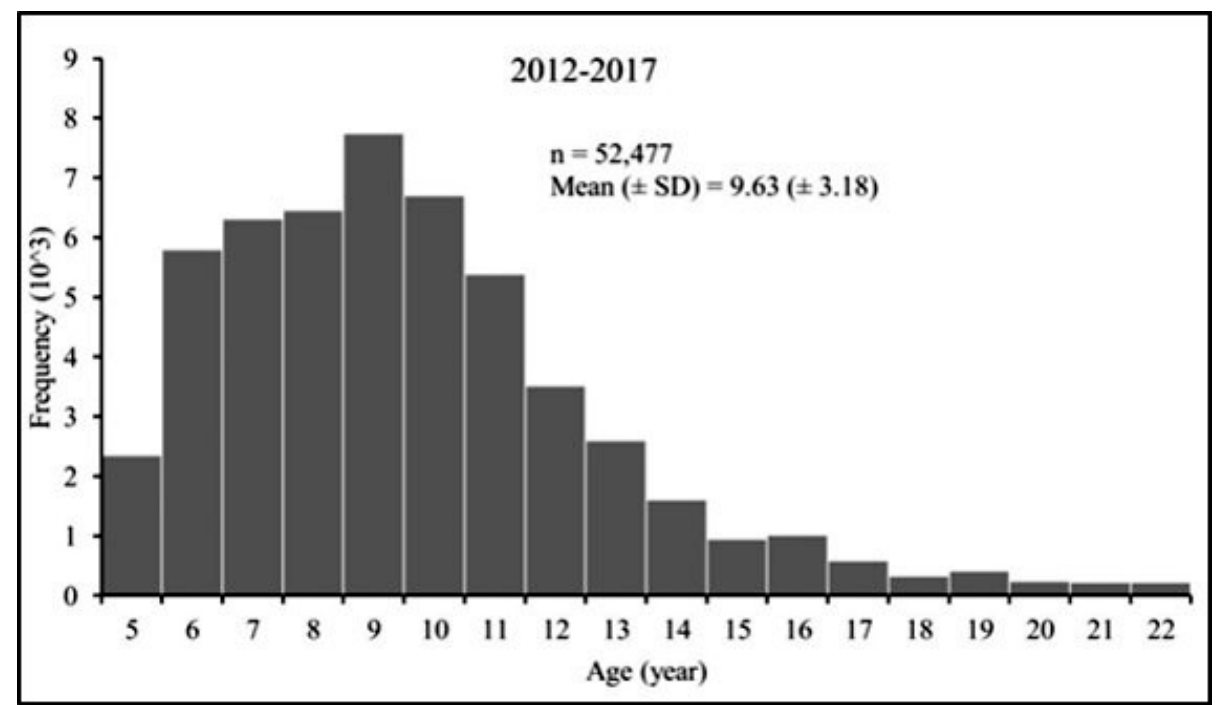

Figure 3. Catch at age structure of fresh Southern Bluefin Tuna (Thunnus maccoyii) caught and landed by Indonesia's tuna longliner in spawning ground area of Indian Ocean in a period of 2012-2017. 




Figure 4. Catch at age structure of fresh Southern Bluefin Tuna (Thunnus maccoyii) caught and landed by Indonesian tuna Longliners in spawning ground area of Indian Ocean in a period of 2012-2017.

\section{Virtual Population Analysis (VPA)}

The result of the age structure virtual population analysis (VPA) indicated that the mode of the fish population in the periods of 2012-2016 shifted to the right position (positive) toward an older fish. SBT population mode is in the age group of 5 years in 2012 and 2013. Respectively, entering 2014 to 2016 the population mode moves to the age group of 6 years, 7 years and 8 years. The percentage of fish caught has increased from $8 \%$ in 2012 and 2013 to $15 \%$ in $2014,27 \%$ in 2015 and $22 \%$ in 2016 . The fishing pressure of SBT caught by Indonesian longliners can be seen in the age group under 20 years. This is caused by the significant number of fish populations in the age group under 20 years compared to fish populations in the age group above 20 years. In 2012, the highest fishing pressure 
obtained in the age group of 13 years with a fishing mortality value of 0.27 year. In 2013 and 2014 the highest fishing pressure shifted towards younger fish at the age of 11 years with a value of fishing mortality of 0.22/ year (2013) and 0.26/year (2014). Entering 2015 , fishing pressure moved to younger fish at the age group of 6 years with the fishing mortality of $0.52 /$ year. The same thing happened in 2016 with the highest fishing pressure at the age of 6 years with a fishing mortality value of 0.68 year (Figure 5 ) and (Appendix 3).

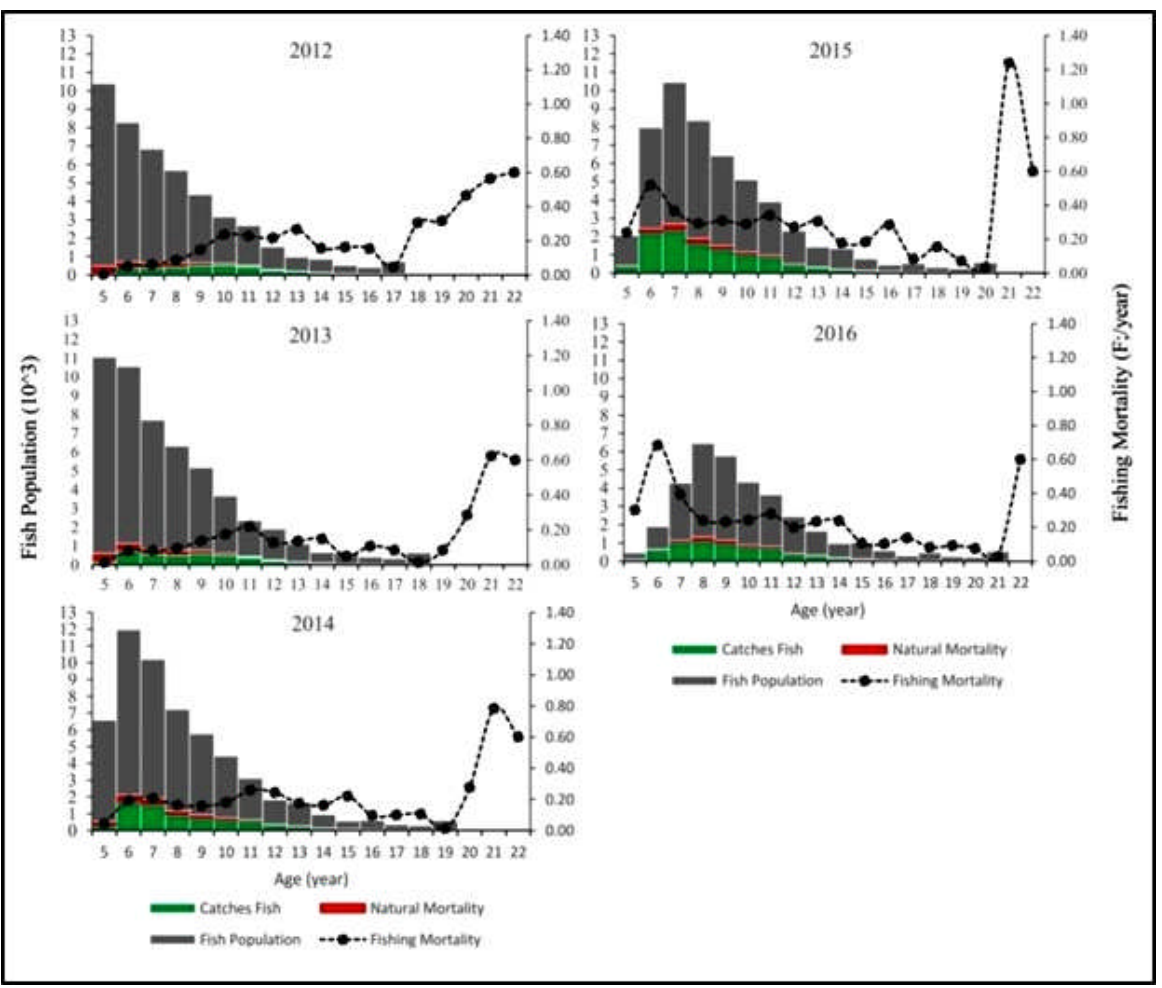

Figure 5. The Virtual Population Analysis (VPA) based on the age structure of Southern Bluefin Tuna (Thunnus maccoyii) caught by Indonesian Longliners in the Indian Ocean in the periods of 2012-2017.

\section{Discussion Growth}

The results of the overall otolith analysis showed that the lowest age was 8 years and the highest was 20 years with a minimum length of $134 \mathrm{cmFL}$ and maximum length of $196 \mathrm{cmFL}$. However, the longest fish is not the oldest fish: The $196 \mathrm{cmFL}$ fish length is 18 years old, younger than the fish with a length of $195 \mathrm{cmFL}$ and $180 \mathrm{cmFL}$ which is 20 years old. It showed that SBT is a species with slow growth and has a high variation in natural size especially fish with age above 10 years. That was reinforced by Gunn et al. (2008) and Shiao, Chang, Lin, and Tzeng (2008) which said that the species of SBT is a long-lived species, has a slow growth coefficient per year and has a high variation in size, especially at the age above 10 years.

The Age-Length Key (ALK) has a narrow life span of 8 to 20 years and a large size of fish $(>138 \mathrm{cmFL})$ so that the ALK produced can only be used specifically to predict the growth and population structure of non- frozen SBT landed by the Indonesian longline fleet which has specific fishing areas in the South off Java, Bali, Nusa Tenggara and within the Indonesian EEZ (Appendix 1). Frozen SBT obtained from the nursery ground area $\left(>20^{\circ} \mathrm{S}, 75^{\circ}-110^{\circ} \mathrm{E}\right)$ cannot be included in this analysis. This is supported by Farley et al. (2014) which states that the catch of SBT captured in spawning ground areas has special criteria compared to fish caught in the nursery ground area. Fish caught in spawning areas are relatively larger in size and caught in shallow waters or low fishing depths.

Southern Bluefin Tuna has a slow type of growth, but at the beginning of the year its development can be grown rapidly (Gunn et al., 2008; Farley et al., 2014). Previous research conducted by Gunn et al. (2008) reported that the SBT at one year of age has an average fork length of $55 \mathrm{cmFL}$. The growth coefficient (male and female) in this study (0.167/year) is slightly higher than the study by Lin and Tzeng (2010) which was informed (xx/year) (2010) in the Central and Southern Indian Ocean of Java, Bali and Nusa Tenggara and Gunn et al. (2008) in the Central 
Indian Ocean. The increasing of the growth coefficient $(\mathrm{K})$ is caused by sexual dimorphism where the coefficient of growth of SBT is higher in spawning area than that the other areas. This size length suggested as the main factor when the early gonad maturity in male and female fish (Farley \& Davis 2003). This sexual dimorphism also occurs in other temperate tuna species, such as albacore (Thunnus alalunga) (Williams et al., 2012). The otolith data showed that there was a sexual dimorphism (length-at-age) between male fish and female fish characterized by the differences in the coefficient of growth. The growth coefficient of male fish is higher than that of female fish so that at the same age has a higher length. This is similar finding from a previous study conducted by Gunn et al. (2008) and Farley et al. (2014). Comparison of Von Bertalanffy's growth curve of this study which is compared with several previous studies (Appendix 2).

The Von Bertalanffy growth model generated from this study shows that the catches of the SBT caught by the Indonesian tuna longliners in spawning areas have a different age structure and length compared with the other fishing area. This study showed that to achieve the ideal length of gonadal maturity $>140 \mathrm{cmFL}$ as reported by (Davis \& Farley, 2001; Gunn et al., 2008; Lin \& Tzeng, 2010) were obtained at ages 6 to 7 years.

While the previous research conducted by Lin and Tzeng (2010) suggested that the level of gonad maturity with a minimum size of $140 \mathrm{cmFL}$ was obtained at the age of 10 to 11 years while Gunn et al. (2008) obtained at the age of 7 years. Farley et al. (2009) found indications that all female fish entering the spawning ground were thought to have matured starting at the age of 6 years with an average length of $145 \mathrm{cmFL}$. The difference in the growth curve that occurred between the studies with the previous research was due to differences in the characteristics of the fish samples that would be taken by the otolith. Different characteristics of fish samples include length interval differences, differences in age intervals, differences in sampling locations and differences in the sexes of SBT which will be used as otolith research material. This difference potentially be source of a difference in the growth coefficient $(\mathrm{K})$, asymptotic length ( $L$ ") and theoretical age when the length is zero $\left(t_{0}\right)$ in the Von Bertalanffy growth equation. The otolith sampling location from the spawning area will be different from the otolith fish sample from the nursery ground or other areas. In addition there is sexual dimorphism between male and female fish with different growth coefficients $(K)$ when it is separated or combined in the analysis. Male fish has a growth coefficient $(K)$ higher than that female fish but has an asymptotic length lower than female fish so that at an adult age ( $>30$ years) individual female fish will continue to grow up to more than 40 years old and male individuals will stop growing at \pm 30 years of age (Figure 2). The same thing was found in the previous studies conducted by Farley et al. (2014) in the SBT otolith in the spawning area south off Java, Bali and Nusa Tenggara, which states that at the age of more than 30 years male fish will stop growing and female individuals will continue to grow until it approaches the asymptotic length.

\section{Catch at Age Structure}

Age frequency data is an important component in stock assessment which serves to reconstruct catchat-age data structures (Sparre \& Venema, 1998; Herrera \& Pierre, 2011). Fishing pressure could be also recognized by the movement of mean age and age mode of SBT caught by Indonesian tuna longliners. The results showed that there was a high fishing pressure in the period 2012-2014 which was marked by the decreasing in the mean age of the catch from 9.69 years to 8.39 years. In addition, the fishing pressure was also marked by the decreasing of the age mode from 10 years in 2012 to 6 years age in 2014. In 2015 to 2017, this research indicated that the fishing pressure was decreased which recognized by the increase of mean age from 8.45 years (2015), 9.28 years (2016) and 10.87 years (2017). The increasing of mode age from 7 years (2015), 9.28 years (2016) and 10.87 years (2017). However, the average age of SBT caught by Indonesian longliners in the Indian Ocean in recent years is still far below the average value of catches in 2000 of 19.5 years and in 2011 of 16.8 years (Farley et al., 2014).

Besides that there are other reasons related to the smaller size and the declining the number of old fish (> 20 years) entering the spawning area where the Indonesian tuna longliners operates, namely the reduction in fishing quotas from 40,000 tons in 1980 to only 10,000 tons in 2006 in the entire area of the Indian Ocean (CCSBT, 2013). This reduction was also seen in juvenile fishing ( \pm 2 years) of SBT in Australian waters from 21,000 tons in 1982 to 5,000 tons in 1990 (Farley et al., 2014). Reduction of juvenile capture in the upbringing area is thought to result in high recruitment of young fish in the spawning area as a pulse 8 to 10 years later. Data on the capture of Indonesia's Southern Bluefin Tuna from 2012 to 2017 is thought to have been a boost (pulse) from juvenile stock from 2004 to 2009 in the nursery ground area. While the decline in the number of old fish ( $>20$ years) tends to be suspected due to the fishing pressure and fishing efforts to both juvenile and adult phases. 


\section{Virtual Population Analysis (VPA)}

Based on the virtual population analysis (VPA), it can be seen the value of natural mortality $(M)$, fishing mortality $(F)$, total mortality $(Z)$ and exploitation rate (U) for the period 2012 to 2016 . The detailed information such as a total fish population, natural mortality, fishing mortality and exploitation rates for each age group of the catches can be determined by VPA analysis (Appendix 3). The fishing mortality (F) in the period of 2012 to 2016 was still in the range of $0.17 /$ year to $0.32 /$ year. The highest fishing pressure was found in the age group of 13 years and 11 years in 2012-2014 with an average length of 167 to 174 cmFL. Whereas in the period of 2015 and 2016 the fishing pressure occurred at the age of 6 years with an average length of $138 \mathrm{cmFL}$. This is supported by the previous research by Evans et al. (2012) by using Pop-up satellite archival tags on SBT which will start spawning activities in the Indian Ocean, which are known to have \pm SD lengths of $169.22 \mathrm{cmFL} \pm 8.73$ and tend to choose areas that have sea surface temperatures between $21.5^{\circ} \mathrm{C}$ to $29.5^{\circ} \mathrm{C}$ at the beginning of February and March. The area with such temperature ranges is a region which not far from the south coast of the islands of Java, Bali and Nusa Tenggara which is the traditional fishing area of the Indonesian tuna longline fleet which may target of SBT.

Fish stock is said to be overfishing or not overfishing is based on the optimal assumption of the exploitation rate $U\left(U_{\text {opt }}\right) H$ " 0.5 (Gulland, 1971). The value of the exploitation rate of SBT caught in the spawning area is presented in (Appendix 3). In the period of 20122016 , the average exploitation rate ranged from $0.14 /$ year to 0.25 /year. This means that the level of exploitation of SBT caught in the spawning area of the Indian Ocean is based on the catch of Indonesia's longline tuna fleet is underfishing. The catch at age structure of SBT caught by Indonesia's longliners also showed that the stock rebuilding is still on going in this time due to the movement of age mode from younger to older fish (7-9 years) from 2015 to 2017 . It was suitable with studied conducted by CCSBT (2017) which uses the MSY reference point as a base of the model. It was stated that the stock status of the SBT caught in the Indian Ocean is not in overfishing or subject to overfishing and still in rebuilding stock. The value of fishing mortality $(F)$ relative to the value of fishing mortality at MSY $\left(\mathrm{F}_{\mathrm{MSY}}\right)$ is not more than 0.5 / year by compiling the fishing quota for CCSBT member countries. The value of MSY in 2017 was 33,036 tons $(30,000-36,000$ tons) and the total allowable catch ( TAC) was 14,647 tons in 2017 and 17,647 tons in the period 2018 to 2020 (CCSBT, 2017).
Population, mortality rate (natural mortality and fishing mortality) and the exploitation rate of SBT can be clearly described in this study. Although the enumeration which was carried out by the RITF (Research Institute for Tuna Fisheries) were not cover the entire capture data of SBT landed at Benoa port, but the VPA size population can be adjusted to the existing data coverage. The average of port based enumeration coverage in Benoa-Bali port from the period of 2012 to 2016 was $\pm 60 \%$ (IOTC, 2017; IOTC, 2018) so that the actual VPA estimation was $40 \%$ higher than the VPA theoretical calculation. But the value of the mortality rate and the rate of exploitation remain the same even though the fishing data and fish populations that live in the natural area have increased by $40 \%$. This research showed that the estimation of adult SBT population that lives in spawning areas was ranged from 4,324 tons to 6,045 tons or 46,478 fish to 78,553 fish and the population was obtained from the addition of about $40 \%$ of the VPA theoretical data from the analysis.

\section{CONCLUSION}

Catch at age structure of SBT caught in spawning area of Indian Ocean ranged from 5 to 22 years old which is dominated by 9 years old with an average age of 9.63 years. SBT has a slow growth type with the Von Bertalanffy growth equation were: $L_{t}=192$ (1$\left.\mathrm{e}^{-0,2297(t+0,439)}\right)$ for males, $L_{t}=196\left(1-\mathrm{e}^{-0,1268(t+0,809)}\right)$ for female and $L_{t}=191\left(1-e^{-0,167(t+1,081)}\right)$ for combined sexes. VPA indicated that the mode of the fish population in the periods of 2012 to 2016 has increased from younger to older fish but fishing pressure changes from older fish to younger fish. The exploitation rate of SBT in the spawning ground area ranged from $0.14 /$ year to 0.25 year, meaning that the level of exploitation was in underfishing status and rebuilding stock

\section{ACKNOWLEDGEMENTS}

The authors thank to "Ministry of Marine Affairs", "Human Resource and Research Agency Marine and Fisheries" and "Fisheries Research Centre" for all financial support. I also would like to thanks and express a high appreciation to the enumerators of the "Research Institute for Tuna Fisheries (RITF)" who have helped to collect data during the research.

\section{REFERENCES}

Beamish, R.J., \& Fournier, D.A. (1981). A method for comparing the precision of a set of age determination. Can. J. of Fish. Aquat. Sci. 38, 982-983. 
CCSBT (Commission for the Conservation of Southern Bluefin Tuna). (2013). Report of the twentieth annual meeting of the commission 14-17 October 2013. 96 pp.

CCSBT (Conservation of Southern Bluefin Tuna). (2016). Report of the Twenty First Meeting of the Scientific Committee. 100 p. [cited 2018 Dec 11]. Available from: URL: https://www.ccsbt.org.

CCSBT (Commission for the Conservation of Southern Bluefin Tuna). (2017). Report of the twenty-second meeting of the scientific committee. $124 \mathrm{pp}$

CCSBT (Commission for the Conservation of Southern Bluefin Tuna). (2018). Annual catch by flag or gear from 1952 to 2017 inclusive. Retrieved from https:/ /www.ccsbt.org/en/content/sbt-data.

Clear, N.P., Gunn, J.S., \& Rees, A.J. (2000). Direct validation of annual increment in otolith of juvenile Southern Bluefin Tuna, Thunnus maccoyii by means of a large scale mark-recapture experiment with strontium chloride. Fish. Bull, 98, 25-40. https://spo.nmfs.noaa.gov/sites/default/files/ 03_2.pdf.

Davis, T.L.O., \& Farley, J.H. (2001). Size distribution of Southern Bluefin Tuna (Thunnus maccoyii) by depth on their spawning ground. Fish. Bull. 99: 381-386. https://www.st.nmfs.noaa.gov/spo/ FishBull/992/dav.pdf.

Evans, K., Patterson, T.A., Reid, H., \& Harley, S.J. (2012). Reproductive schedules in Southern Bluefin Tuna: Are current assumptions appropriate? PlosONE 7(4):e34550.doi:10.1371/ journal.pone.0034550.h t ps: / / search.proquest.com/docview/1324444065/ fulltextPDF/1580A04ACA6740A9PQ/ 2 ?accountid $=32506$

Farley, J.H., \& Davis, T.L.O. (1998). The reproductive dynamic of Southern Bluefin Tuna, Thunnus maccoyii, as inferred from direct age data. Fish Bull, 96, 223-236. https://www.researchgate.net/ publication/258883653_Reproductive_ dynamics_of_southern_bluefin_tuna_ Thunus_maccoyii.

Farley, J.H., \& Davis, T.L.O. (2003). Length and age distribution of SBT in the Indonesian longline catch on the spawning ground. Report CCSBT/ESC/ 0309/18. 17 pp.
Farley, J.H., Andamari, R., \& Proctor, C.H. (2009). Update on the length and age distribution of SBT in the Indonesian longline catch. Working paper CCSBT/SC/0909/15 prepare for the $14^{\text {th }}$ meeting of the scientific committee of CCSBT (incorporating the Extended Scientific Committee), 5-11 September 2009. Busan, Korea.13 pp.

Farley, J.H., Eveson, J.P., Davis, T.L.O., Andamari, R., Proctor, C.H., Nugraha, B., \& Davies. C.R. (2014). Demographic structure, sex ratio and growth rate of Southern Bluefin Tuna (Thunnus maccoyii) on the spawning ground. PLOS ONE 9(5), e96392. doi:10.1371/ journal. Pone.0096392.https: / / search.proquest.com/docview/1520987655/ full textPDF/ 7 E 08785786 E 4922 PQ/ 1 ? accountid $=32506$

Fry, F.E.J. (1949). Statistic of a lake trout fishery. Biometrics. 5, 27-67. https://www.jstor.org/stable/ $\begin{array}{lllllllllllll}3 & 0 & 0 & 1 & 8 & 9 & 0 & \text { ? } & \mathrm{r} & \mathrm{e} & \mathrm{a} & \mathrm{d} & \text { - }\end{array}$ now $=1 \&$ seq=1\#page_scan_tab_contents

Gulland, J.A., \& Holt, S.J. (1959). Estimation of growth parameters for data at unequal time intervals. ICES Journal of Marine Science 25(1), 47-49. https:// doi.org/10.1093/icesjms/25.1.47

Gulland, J.A. (1971). The fish resources of the oceans (p. 255): FAO Fishing News (Books) Ltd. Surrey.

Gunn, J.S., Farley, J.H., \& Hearn, B. (2008). Catch at age; age at first spawning; historical change in growth; and natural mortality of SBT; An integrated study of key uncertainties in the population biology and dynamic of SBT based on direct age estimates from otolith. FRDC Project no.97/111. Hobart, Australia; CSIRO Marine Research. 97 pp.

Herrera, M., \& Pierre, L. (2011). Preparation of data input files for the stock assessment of Indian Ocean Swordfish. IOTC-2011-WPB09-07. 32 pp.

IOTC (Indian Ocean Tuna Commission). (2017). Indonesian National Report to the Scientific Committee, 2017. IOTC-2017-SC20-NR09. 24 pp.

IOTC (Indian Ocean Tuna Commission). (2018). Indonesian National Report to the Scientific Committee, 2018. IOTC-2018-SC21-NR09. 28 pp.

Klawe, W.L. (1980). Longlines catch of tunas within the 200 miles economic zones of the Indian and Western Pacific Ocean. Dev. Rep. Indian Ocean Prog. 48, 83. 
Lin, Y.T., \& Tzeng, W.N. (2010). Sexual dimorphism in the growth rate of Southern Bluefin Tuna Thunnus maccoyii in the Indian Ocean. J. Fish. Soc. Taiwan, 37(2), 135-151. http://ntur.lib.ntu.edu.tw/retrieve/ $174675 /$

Patterson, T.P., Evans, K., Carter, T.I., \& Gunn, J.S. (2008). Movement and behavior of large Southern Bluefin Tuna (Thunnus maccoyii) in the Australian region determined using pop-up satellite archival tags. Fish Oceanog, 17, 352-367. http:// www.cmar.csiro.au/biologging4/documents/ FOG_finalversion.pdf

Pauly, D. (1984). Fish population dynamic in tropical waters: A Manual for Use with Programmable Calculators. ICLARM Studies and Reviews, 8. 325 p.

Pope, J.G. (1972). An investigation of the accuracy of virtual population analysis using cohort analysis. Research Bulletin ICNAF, (9), 65-74. https:// www.nafo.int/icnaf/library/res-bull/res-bull9.pdf\#page $=65$.

Proctor, C.H., Andamari, R., Retnowati, D., Herrera, M., \& Poisson, F. (2006). The catch of SBT by the Indonesian longline fishery operating out of Benoa, Bali in 2005. Report CCSBT-ESC/0609/10 prepared for the $11^{\text {th }}$ CCSBT Extended Scientific Meeting 4-11 September, Tokyo, Japan

Rochman, F. (2019). The utilization of otolith in the study of dynamic population and age structure of Southern Bluefin Tuna, Thunnus maccoyii (Castelnau, 1872) Caught in the Indian Ocean (Postgraduate Thesis). Mathematics and Natural Science, Udayana University, Bali, Indonesia. 103 p.

Rochman, F., Setyadji, B., \& Jatmiko, I. (2016). Impact of the moratorium enforcement on the fishing effort and production of industrial-scale longline tuna fisheries based in Benoa Port-Bali. Ind.Fish.Res.J, 22(3), 181-188. http://ejournalbalitbang.kkp.go.id/index.php/ippi/article/view/ $\underline{1545 / 2735 .}$

Satria F., Suman, A., Nugroho, D., Nugraha, B., \& Widodo, A. (2012). Indonesian southern Bluefin tuna fisheries, a national report year 2011. Report CCSBT-ESC/1208/SBT Fisheries-Indonesian prepared for the $17^{\text {th }}$ CCSBT Meeting of the Scientific Meeting 27-31 August, Tokyo. Japan. $13 \mathrm{pp}$.

Setyadji, B., (2015). Dynamic population of swordfish (Xiphias gladius L.) in the Indian Ocean (Postgraduate Thesis). Mathematics and Natural Science, Udayana University, Bali, Indonesia. 68 pp.

Shiao, J.C., Chang, S.K., Lin, Y.T., \& Tzeng, W.N. (2008). Size and age composition of Southern Bluefin Tuna (Thunnus maccoyii) in the Central Indian Ocean inferred from fisheries and otolith data. Zoological studies. 47(2): 158-171. http:// ntur.lib.ntu.edu.tw/bitstream/246246/174809/1/ 13.pdf.

Shimose, T., \& Ishihara, T. (2015). A manual for age determination of Pacific Bluefin tuna (Thunnus orientalis). Bull. Fish. Res. Agen. No. 40: 1-11. https://www.fra.affrc.go.jp/bulletin/bull/bull40/4001.pdf.

Sparre, P., \& Venema, S.C. (1998). Introduction to tropical fish stock assesment. Part 1: manual. FAO Fisheries Technical Paper, 306/1 Rev. 2, (FAO Rome): $407 \mathrm{p}$.

Williams, A.J., Farley, J.H., Hoyle, S.D., Davies, C.R., \& Nicol, S.J. (2012). Spatial and sex-specific variation in growth of albacore (Thunnus alalunga) across the South Pacific Ocean. PLOS ONE. 7(6): e39318, doi: 10.1371/journal. 
Ind.Fish.Res.J. Vol. 25 No. 2 December 2019: 75-90

Appendix 1. Otolith image reading of Southern Bluefin Tuna sample of this research study

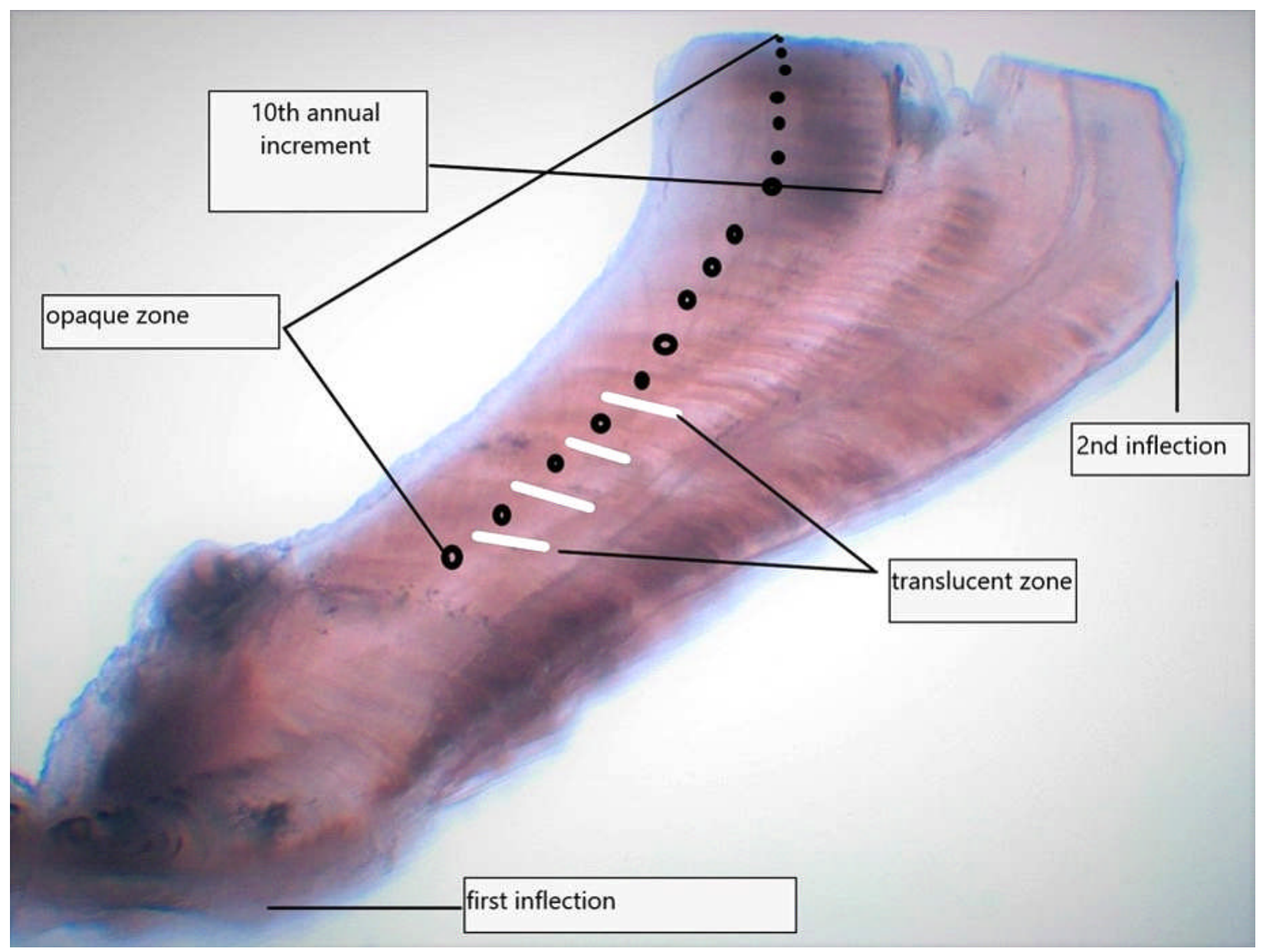

Appendix 2. Mean of length ( $\mathrm{cmFL}$ ) and standard deviation of Southern Bluefin Tuna (Thunnus maccoyii) based on the otolith age reading.

\begin{tabular}{rrrrr}
\hline $\begin{array}{c}\text { Age Group } \\
\text { (Year) }\end{array}$ & The Average of Length (cmFL) & SD $( \pm)$ & $\mathrm{n}$ \\
\hline 8 & 138 & 4.24 & 2 \\
9 & 140.75 & 0.96 & 4 \\
10 & 148.30 & 8.29 & 43 \\
11 & 150.75 & 6.77 & 75 \\
12 & 156.89 & 7.27 & 83 \\
13 & 162.62 & 8.99 & 89 \\
14 & 170.41 & 8.57 & 63 \\
15 & 171.36 & 6.36 & 53 \\
16 & 173.90 & 7.37 & 20 \\
17 & 175.50 & 5.39 & 9 \\
18 & 181.37 & 10.25 & 8 \\
19 & 187 & - & 1 \\
20 & 187.50 & 10.6 & 2 \\
\hline Total & & & 452
\end{tabular}


Appendix 3. The result of several studies regarding the age and growth of Southern Bluefin Tuna (Thunnus maccoyii) in the Indian Ocean.

\begin{tabular}{|c|c|c|c|c|c|c|}
\hline $\begin{array}{c}\mathrm{L}_{\infty} \\
(\mathrm{cm}) \\
\end{array}$ & $\begin{array}{c}\mathrm{K} \\
\text { (1/Year) }\end{array}$ & $\mathrm{t}_{0}$ & Sex & Methods & Location & Refference \\
\hline 219.70 & 0.135 & -0.040 & Combination & Annulus scale & Japan & Yukinawa, 1970 \\
\hline 180.84 & 0.146 & -0.011 & Combination & Tagging & Australia & Murphy, 1977 \\
\hline 222.50 & 0.140 & 0.011 & $\begin{array}{l}\text { Combination } \\
\text { Combination }\end{array}$ & Annulus scale & Japan & Shingu, 1978 \\
\hline 207.60 & 0.128 & -0.394 & Combination & $\begin{array}{l}\text { Tagging and length freq., at the age }<9 \\
\text { years }\end{array}$ & Central Indian Ocean & Kirkwood, 1983 \\
\hline 261.30 & 0.108 & -0.157 & Combination & Otolith, mainly at the age of $<6$ years & Central Indian Ocean & Thorogood, 1987 \\
\hline 183.90 & 0.180 & -1.322 & Combination & $\begin{array}{l}\text { Tagging and length freq, at the age of } 1 \text { - } \\
12 \text { years and }>12 \text { years }\end{array}$ & Australia & Polacheck et al., 1996 \\
\hline 183.18 & 0.185 & -0.923 & Combination & Otolith, at the age of $1-41$ years & $\begin{array}{l}\text { Central Indian Ocean and } \\
\text { Indian Ocean South off Java, } \\
\text { Bali and Nusa Tenggara island }\end{array}$ & Gunn et al., 2008 \\
\hline 211.66 & 0.093 & -1.602 & Male & Otolith, at the age of $2-21$ years & $\begin{array}{l}\text { Central Indian Ocean and } \\
\text { Indian Ocean South off Java, } \\
\text { Bali and Nusa Tenggara island }\end{array}$ & Lin dan Tzeng, 2010 \\
\hline 192.38 & 0.109 & -1.753 & Female & Otolith, at the age of $2-21$ years & $\begin{array}{l}\text { Central Indian Ocean and } \\
\text { Indian Ocean South off Java, } \\
\text { Bali and Nusa Tenggara island }\end{array}$ & Lin dan Tzeng, 2011 \\
\hline 192.00 & 0.230 & -0.439 & Male & Otolith, at the age of $8-20$ years & $\begin{array}{l}\text { Indian Ocean South off Java, } \\
\text { Bali dan Nusa Tenggara island }\end{array}$ & 2019 (This study) \\
\hline 196.00 & 0.127 & -0.809 & Female & Otolith, at the age of $8-20$ years & $\begin{array}{l}\text { Indian Ocean South off Java, } \\
\text { Bali dan Nusa Tenggara island }\end{array}$ & 2019 (This study) \\
\hline 191.00 & 0.167 & -1.081 & Combination & Otolith, at the age of $8-20$ years & $\begin{array}{l}\text { Indian Ocean South off Java, } \\
\text { Bali dan Nusa Tenggara island }\end{array}$ & 2019 (This study) \\
\hline
\end{tabular}

Information:

$L_{n}:$ : Asymptotic length (cmFL)

$\mathrm{K}$ :Growth coefficient (1/year)

$t_{0}:$ Theoretical age when the length equal to 0 
Ind.Fish.Res.J. Vol. 25 No. 2 December 2019: 75-90

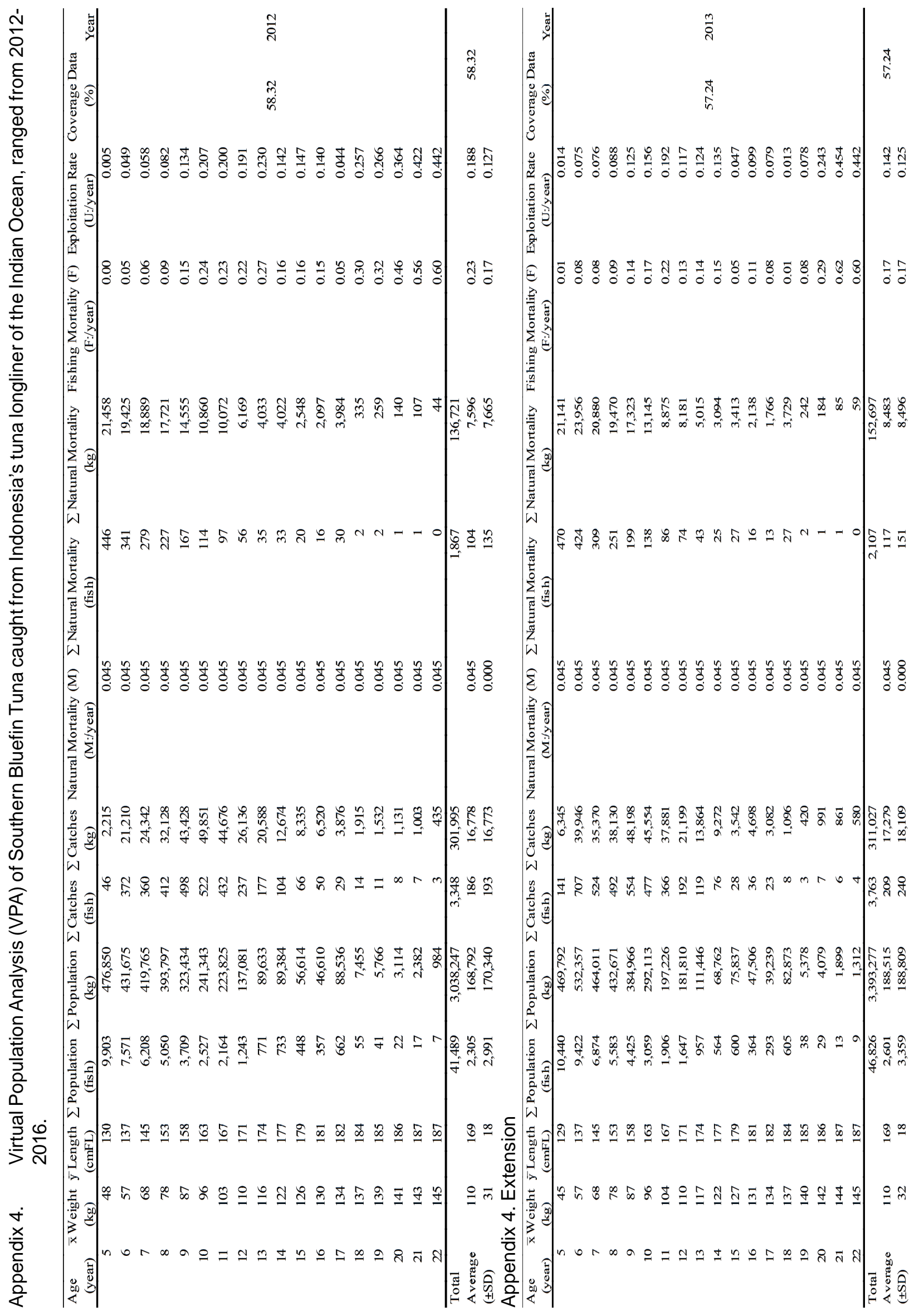




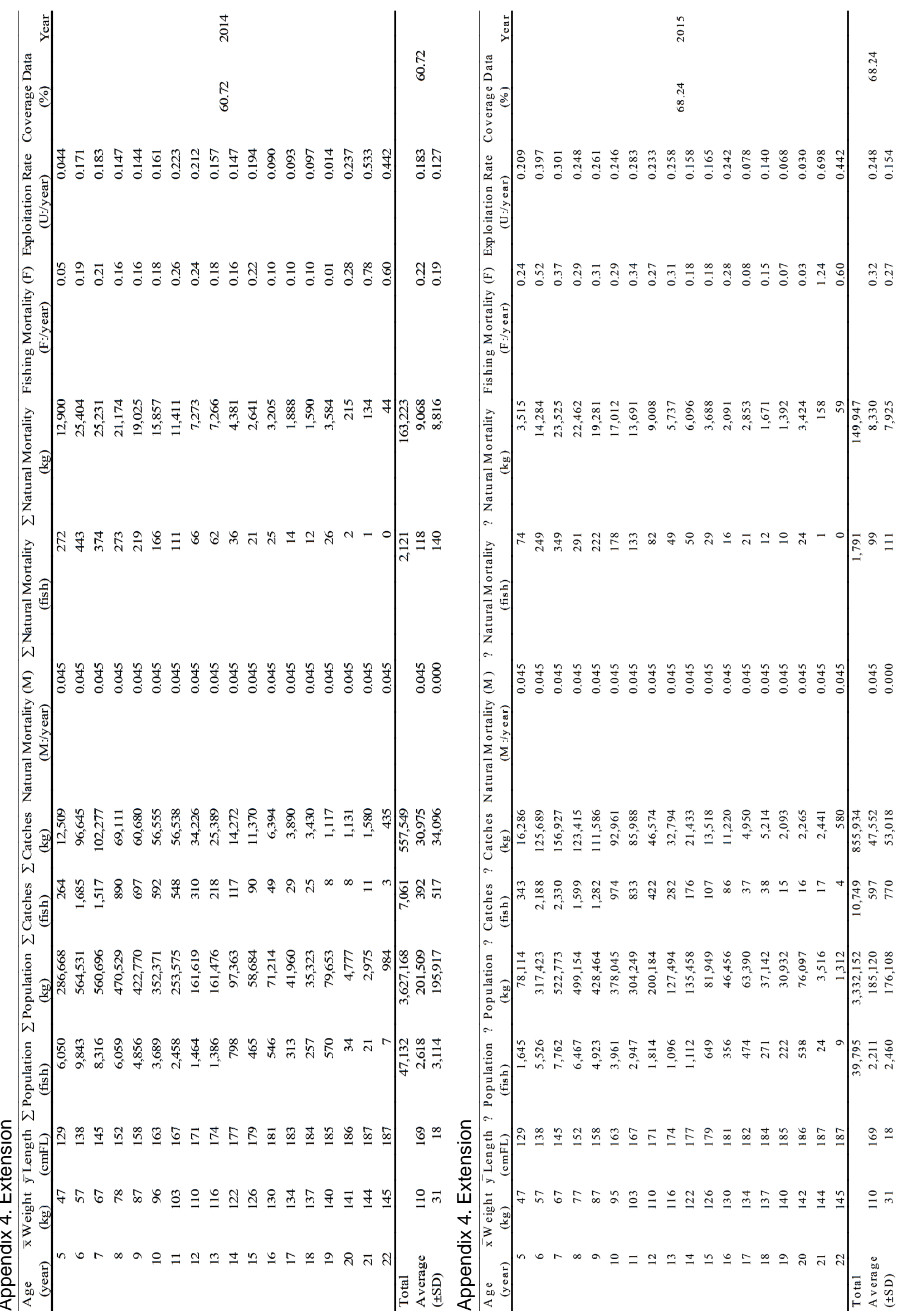


Ind.Fish.Res.J. Vol. 25 No. 2 December 2019: 75-90

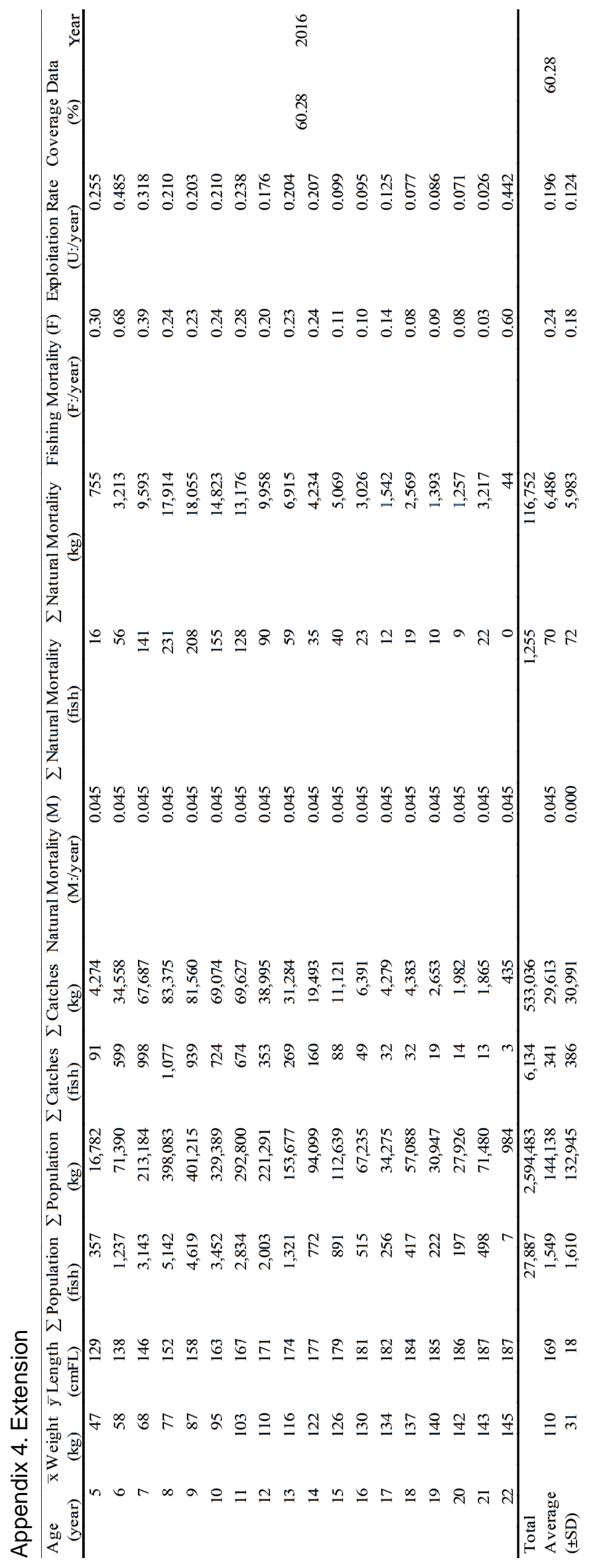

